NBER WORKING PAPER SERIES

\title{
THE INVENTION OF INFLATION-INDEXED BONDS \\ IN EARLY AMERICA
}

Robert J. Shiller

Working Paper 10183

http://www.nber.org/papers/w10183

\author{
NATIONAL BUREAU OF ECONOMIC RESEARCH \\ 1050 Massachusetts Avenue \\ Cambridge, MA 02138 \\ December 2003
}

The views expressed herein are those of the authors and not necessarily those of the National Bureau of Economic Research.

(C)2003 by Robert J. Shiller. All rights reserved. Short sections of text, not to exceed two paragraphs, may be quoted without explicit permission provided that full credit, including $(\mathcal{C}$ notice, is given to the source. 
The Invention of Inflation-Indexed Bonds in Early America

Robert J. Shiller

NBER Working Paper No. 10183

December 2003

JEL No. E31

\section{$\underline{\text { ABSTRACT }}$}

The world's first known inflation-indexed bonds were issued by the Commonwealth of Massachusetts in 1780 during the Revolutionary War. These bonds were invented to deal with severe wartime inflation and with angry discontent among soldiers in the U.S. Army with the decline in purchasing power of their pay. Although the bonds were successful, the concept of indexed bonds was abandoned after the immediate extreme inflationary environment passed, and largely forgotten until the twentieth century. In 1780, the bonds were viewed as at best only an irregular expedient, since there was no formulated economic theory to justify indexation.

Robert J. Shiller

Yale University, Cowles Foundation

Box 208281

30 Hillhouse Avenue, Room 23a

New Haven, CT 06520-8281

and NBER

robert.shiller@yale.edu 
The Invention of Inflation-Indexed Bonds in Early America

Robert J. Shiller

The world's first known inflation-indexed bonds were issued by the Commonwealth of Massachusetts in 1780 during the Revolutionary War. These were issued to U.S. soldiers as deferred compensation for their service, and were called "depreciation notes" or "soldiers' depreciation notes." While there are earlier examples of measures to compensate people for the loss of purchasing power of their money, this appears to be the first time that a debt contract specified payments formally linked to a price index. ${ }^{1}$

This important invention came to light in an environment where stark necessity spurred invention, and where practical people under pressure devised these bonds as an immediate expedient to deal with problems they must have regarded as of life-and-death importance to them. The longterm significance of these bonds, to be issued by other entities much later and in more normal times, came to be appreciated by scholars only decades, even centuries, later.

Those anonymous people who made this invention in 1780 apparently did so without the help of any academic or theoretical literature on indexation. John Maynard Keynes is widely quoted as

${ }^{1}$ Of course, it is not absolutely known that this is the first indexed bond. Willard Fisher, who studied these Massachusetts bonds extensively, wrote "It is by no means impossible that a story of similar monetary or fiscal policy may lie hidden in the records of other states whose early histories have not been studied as much as the history of Massachusetts. There certainly was no little endeavor for harmonious action among the New England states in matters of financial policy" (Fisher, 1913, p. 448). Fisher points out that Governor George Clinton of New York (the uncle of the later, and now more famous, New York Governor DeWitt Clinton) expressed interest in the Massachusetts indexed bonds in 1780. By extension, we can easily imagine that the Massachusetts experience derives from imitation or extension of some now forgotten earlier example. 
asserting that most economic innovations derive ultimately from some "academic scribblers." ${ }^{2}$ But, in fact, in the case of indexed bonds, there was no academic precursor.

As of 1780 , there appears to have been no mention at all in any scholarly literature of indexed bonds or even of the concept of indexation. Ninety years ago Wesleyan University Professor Willard Fisher sought to find an earlier reference to indexation and the best he could find was a statement by Adam Smith, four years before 1780 , that seems at best to refer to the concept only obliquely, and dismissing it. ${ }^{3}$ Histories of the theory of indexation often start with William Stanley Jevons, who wrote expansively in favor of indexed bonds and other indexed contracts in 1875. A much earlier, if less eloquent reference, and apparently the first clear treatment of the concept of indexation, is Joseph Lowe, in 1822. That was already 42 years after the Massachusetts issuance of indexed bonds. The usual history of the actual creation of indexed bonds starts in the twentieth century. Prof. Irving Fisher of Yale University made the advocacy of inflation-indexed bonds a lifelong campaign of his, and the company he co-founded, the Rand-Kardex Co., first issued inflation-indexed bonds in 1925. There were no imitators for some years, and he died in 1947 with little evidence that his campaign was a success. Finland introduced indexed bonds in 1945, Israel and Iceland in 1955,

2"Practical men, who believe themselves to be quite exempt from any intellectual influences, are usually the slaves of some defunct economist. Madmen in authority, who hear voices in the air, are distilling their frenzy from some academic scribbler of a few years back." John Maynard Keynes, The General Theory of Employment, Interest and Money, 1936, Ch. 24 v.

${ }^{3}$ Adam Smith wrote "Labour, it must always be remembered, and not any particular commodity or set of commodities, is the real measure of the value of silver and of all other commodities." The Wealth of Nations, Nicholson's edition, p. 79. Willard Fisher was apparently correct that this passage, by referring to the possibility of a set of commodities as an indicator of value, indicates at least an intuitive awareness of the possibility of indexation. Perhaps Smith would have preferred wage-indexed bonds to inflation-indexed bonds, for which an argument can indeed be made. 
Brazil in 1964, Chile in 1966, Columbia in 1967, Argentina in 1972, the United Kingdom in 1975, Australia in 1985, Mexico in 1989, Canada in 1991, Sweden in 1994, New Zealand in 1995, United States in 1997, and France issue indexed bonds for the euro area in 1998. This period, from 1925 to the end of the $20^{\text {th }}$ century, appears to have been a period of the very slow dissemination of the concept of indexed from the advocacy of Irving Fisher and others of his time. ${ }^{4}$ This huge worldwide explosion of indexed bonds began 145 years after the first example was issued.

The 1780 Issue of Inflation-Indexed Bonds

Already by 1780, the state of Massachusetts had had longstanding problems with an unstable price level due to the state government's excessive printing of paper money. These problems had persisted for the better part of a century when the depreciation notes were issued. Inflation had been a deep-set problem that accounted for a lot of the problems of the state, and that had occupied a great deal of public attention over these years.

The problems started with the Massachusetts government's attempt to pay for an unsuccessful 1790 invasion of Quebec during King William's War (1689-97). Unable to pay its soldiers immediately, the state government resorted to printing paper money that it promised to redeem later. These were bearer notes, and so many or most of the soldiers spent them immediately, and the notes entered circulation as a form of paper money. Since they were not immediately redeemable in specie, they sold at a discount, a discount which varied through time not only due to changes in discount rates but also due to changes in public perceptions of the likelihood that they

\footnotetext{
${ }^{4}$ See Campbell and Shiller (1996).
} 
would eventually be paid in specie. ${ }^{5}$

Further such notes were issued to soldiers during Queen Anne's War (1702-13). Massachusetts issued more paper money than it could reasonably be expected to repay. Printing of money continued, and public faith in the paper declined, and it then sold at a substantial discount from sterling for many years.

Already by 1743, the Governor of Massachusetts William B. Shirley (1694-1771) wrote of these problems in a report to the Board of Trade, that in the last thirty years the currency had "gradually sunk in their value from forty to four hundred forty percent below sterling money." Since a 1712 law had made the local currency legal tender at face value for all debts, he noted that losses were incurred by "creditors of all kinds who had had dealings with the people of New England, and had not been cautious enough to ascertain the value of their debts, by special contracts for the payment of "em, either in sterling or proclamation money."6

The intellectual environment in New England then had apparently prepared the way for this innovation, and evidence of this environment can be found as early as 1742 in legislation, in Massachusetts, that specified that, in times of highly depreciated currency, court judgments should take account of the depreciation as calculated using the exchange rate between a new local currency, later called equity bills, and the British pound sterling. Similar legislation was enacted around that

${ }^{5}$ One lively source of debate that arose is whether the government should ultimately pay the notes in full, when the benefit accrues to the "speculators" who bought the notes at a discount, rather than the soldiers who sacrificed for their country. A leading economist of the time, Pelatiah Webster [1791], argued strongly for paying the notes in full.

${ }^{6}$ William B. Shirley, Report to the Board of Trade Boston, December 23, 1743, as quoted in John Gorham Palfrey, History of New England, Boston: Little, Brown \& Co., 1890. Proclamation money refers to an amount of Spanish milled dollars corresponding to the pound sterling as prescribed in a proclamation of Queen Anne in 1704. 
time in Connecticut, New Hampshire, and Rhode Island. This legislation established a precedent for acknowledging the effects of a depreciation of the currency.

The costs of King George's War (1744-48) threatened to destroy the value of the large amount of currency issued by Massachusetts to pay for the war. A further crisis was avoided by the fact that Britain, in whose behalf Massachusetts had fought the war, shipped over enough solid coin to redeem the new currency.

Problems reappeared when the state of Massachusetts once again issued paper money to pay for its part in the Revolutionary War. Once again, the state government could not raise enough money through taxes to pay for its part in the war, and once again the soldiers were paid in bearer notes that they were obliged to sell immediately at a substantial discount. The wartime inflation meant that soldier's pay was losing much of its value between the time promised and actually received, and by the time the soldiers were able to spend or send it to their families to spend it. The soldiers had been paid in nominal terms only, but had been cheated by inflation out of their real pay, a situation that strongly discouraged their willingness to serve their country further.

A Massachusetts Act of 1777 called "An Act to Prevent Monopoly and Oppression" attempted to deal with the problem of inflation by fixing prices. The act gave a list of prices measured in Massachusetts pounds of 50 commodities in Boston, to be used at that time to allow government fixing of prices to forestall wartime inflation. The price-fixing policy was disastrous. It substantially shut down the market for these basic needs, and was quickly abandoned. Some other expedient was clearly necessary to assure just compensation of soldiers.

By the late 1770s, when these first inflation-indexed bonds were conceived and designed, the U.S. War of Independence was in a difficult stage. In 1779, the British Army had just captured the 
state of Georgia and had taken Charleston South Carolina. The eastern seaboard of the United States was blocked by the British Navy. The morale of the United States Army was low: They were poorly fed, poorly clothed, and often sick. The morale was so low that, as we now know, there were actual army mutinies in 1780 and 1781 . There was real concern in 1779 that it would be impossible to keep an army if something were not done to address the loss of value of their pay. The invention of indexed bonds came in response to this very real and dangerous crisis.

The U.S. Congress issued a letter in 1779 to be read by ministers, from the pulpit, that detailed the problem: "The present situation of public affairs demands your most serious attention, and, particularly, the great and increasing depreciation of your currency requires the immediate and strenuous and united efforts of all true friends to their country, for preventing an extension of the mischiefs that have already flowed from that source .... Our enemies prosecuting the war by sea and land with implacable fury and with some success, taxation at home and borrowing abroad, in the midst of difficulties and dangers, were alike impracticable. Hence, the continued necessity of new emissions."7 The monetary situation was therefore an inevitable consequence of the precarious situation of the nation, its resolution an inherent aspect of the defense of the nation, and as part of patriotic duty Congress called upon the states to take measures to assure that its soldiers were fairly compensated. The Massachusetts legislature passed a resolution on February 6, 1779 to give just settlement of the soldiers' claims, and committees were established that would propose adjustments. The work of these committees led then to the creation of the indexed bonds.

The depreciation bonds were created in Massachusetts by "An Act to provide for the Security and Payment of the Balances that may appear to be due by Virtue of a Resolution of the General 
Assembly of the sixth of February, One Thousand Seven Hundred and Seventy-nine, to this States Quota of the Continental Army, agreeable to the Recommendation of Congress, and for Supplying the Treasury with a Sum of Money for that Purpose," January 13, 1780. The Act was part of an effort to live up in substance to the promise of the 1777 Act which had failed to fix prices. Unable to fix prices, the government of Massachusetts did the next best thing, to provide enough income to their soldiers so that they could buy the basket of goods defined by [a subset of] the list of goods in the 1777 act as if they still had their specified prices. Perhaps due to the difficulties of collecting price data, the indexed bonds were based on only 4 of the 50 commodities described in the 1777 act.

We can read from these engraved bonds themselves (and surrounded by a border apparently in the hand of the official engraver for Massachusetts, Paul Revere) the terms of the indexation. An example of these bonds, dated January 1, 1780, is reproduced here as Figure 1.

Both Principal and Interest to be paid in the then current Money of said $\mathrm{S}_{\mathrm{TATE}}$, in a greater or less Sum, according as Five Bushels of CORN, Sixty-eight Pounds and four-seventh Parts of a Pound of BEEF, Ten Pounds of SHEEPS WOOL, and Sixteen Pounds of SOLE LEATHER shall then cost, more or less than One Hundred and Thirty Pounds current money, at the then current Prices of said ARticles-This Sum being Thirty-two times and an Half what the same Quantities of the same Articles would cost at the Prices affixed to them in the Law of this State made in the Year of our Lord One Thousand Seven Hundred and Seventy-seven, intitled, "An Act to prevent Monopoly and Oppression."

The paragraph defines a price index, specified as it is in terms of fixed quantities of the articles. The index equaled 4.0 in 1777 and 130.0 in 1780, a 32-fold increase. Calculations of the amount owed to soldiers in light of this depreciation of their pay were made. The soldiers were then given in 1780 , to settle their claims, the inflation-indexed bonds, divided into four equal parts. Those who enlisted for the rest of the war were given shorter maturities, four notes maturing in 1781, 1782, 1783 and 1784.

\footnotetext{
${ }^{7}$ Quoted in Joseph Felt (1839), pp. 180-81.
} 
Others were paid in notes maturing in 1785, 1786, 1787 and 1788. A Table from the Act showing calculation of the index for 1777 to 1780 appears here as Table 1 .

The quantities used to define the index were apparently not arrived at by reference to any representative market basket. Certainly, it is far more likely that a family would consume five bushels of corn than 16 pounds of sole leather in a year's time. The quantities were instead defined so that they represent equal currency values of the commodities in 1777. According to the 1777 Act, "Good Indian meal or corn" cost 4 shillings a bushel, "good merchantable sheeps wool" 2 shillings a pound, "good well-fatted grass fed beef" three pence a pound, "stall fed beef, well fatted" 4 pence a pound, and "tanned hides" one shilling 3 pence a pound. The quantities specified on the bond all cost $£ 1$ at these prices (where the two beef prices are averaged to be 3.5 pence a pound.) This index is neither Laspeyres or Pasche, but might be roughly justified in terms of a model which asserts that the price change of each commodity equals an underlying inflation rate plus a noise term that is, measured as a fraction of base year price, independent across commodities and identically distributed. $^{8}$

Once in place, the indexation implicit in the Massachusetts indexed bonds led to at least one other application of the index. The index was used to index the pay of the President of Harvard College, Samuel Langdon. The account, reproduced here as Table II, shows the pay that President Langdon received from 1774 to 1780 according to his promised rate of pay of $£ 200$ per annum, along with the real value, in January 1775 prices, of these payments, as well as of some other, much larger,

${ }^{8}$ Such an index would be dictated by a model that asserts that each commodity has a price proportional to an aggregate price level plus an error which is independent of all other commodities. Such a model resembles that of the repeat-sales price indexes for individual homes, see Baily Muth and Nourse (1963), or its arithmetic counterpart, Shiller (1991). 
payments that were made to him in 1780, apparently in an effort to compensate him for the real value of his pay lost to inflation. The account converts all these payments to 1775 prices, and sums them. The difference between this sum and the sum of the actual payments is the amount owed to President Langdon, in January 1775 prices. This then is an early, perhaps the first, cost of living allowance in a civilian labor contract.

The beginning of indexed bonds, and of indexation more generally, in 1780 was a bright spot in the history of financial innovation. But, unfortunately, it did not stick. The notes were soon replaced. A 1782 Act provided for the eventual consolidation of the state debt, and the replacement of the depreciation notes with new specie securities. The consolidation was complete by 1786 , two years before the maturity of the longest-dated notes issued in 1780. In 1786 an Act stipulated that “...it is altogether unnecessary that the Committee, or Agents, appointed for the collecting and ascertaining the value of the several articles specified in the Notes issued for the pay of the late Continental Army, commonly called depreciation Notes, be any more contained in office." ${ }^{, 9}$ The experiment with indexed bonds ends abruptly, and with no explanation.

Despite its abrupt end, the invention of indexation in Massachusetts in 1780 is a real example of significant financial innovation. It helped solve some real and pressing problems facing a new nation, and did so in a logical and orderly way that could have been generalized to solve many other subsequent monetary policies.

\footnotetext{
${ }^{9}$ Quoted in Willard Fisher (1913), p. 447. From Massachusetts Archives, 237, p. 477.
} 


\section{The Role of Economic Theory in Promoting Indexation}

It seems here that necessity was the mother of this invention. The example of the creation of indexed bonds in Massachusetts in 1780 appears to deny the importance of the "academic scribblers" that Keynes extolled, for the invention appeared long before the scholars wrote about it. And yet, in another sense, it only reinforces their importance, for the practice of indexation of bonds did not take hold at that time. It is a reasonable supposition that the indexed bonds did not continue because there was no well-conceived model that would justify and explain them.

Since the indexation was proposed in 1780 only as an expedient for dealing with a most pressing temporary problem, there was no economic theory suggesting its fundamental importance. When the Revolutionary War ended in 1783, there was thus no more perceived need for these bonds. Collecting data and computing a price index consumes resources, and if inflation is no longer a pressing and immediate issue, then indexation might plausibly be dropped. The price index used was very crude, and its defects might be seen to outweigh its advantages in a time of relatively stable prices. In fact, however, the history of the United States in the $19^{\text {th }}$ century reveals considerable instability of prices, and so it would have been better if the indexation had been continued.

The failure to pursue the idea of indexation after 1780 may also be due to some of the problems of index number theory. We can imagine that there was some intuitive grasp of the problems of price indexes that were later resolved by index number theorists. As time went on, in the $20^{\text {th }}$ century, index number theorists realized that there is a substantial problem with a simple index such as that used in Massachusetts in 1780. If one of the commodities used to define the index became scarce, a shortage of it develops, and the price of that commodity might jump very high. Consumers would normally substitute for another commodity, and thus would not need as much 
money as indicated by the price index to maintain their standard of living. The price index would then jump sharply, and become unrepresentative of the increase in the true cost of living. If bondholders are paid the amount specified in the index formula, then they will enjoy a windfall, since they can just switch their consumption to other commodities that are not in short supply, and find that their purchasing power has been increased dramatically by the indexation. The bond issuers, on the other side of the transaction, are similarly affected, but in the opposite direction.

Well into the $20^{\text {th }}$ century Irving Fisher proposed that the solution to this problem is to tie indexed payments to a sort of price index that he called an "ideal index." The Fisher ideal index has no predictable bias. Now, after the end of the twentieth century, there is clear recognition of the significance of an ideal index, and efforts are being made in many countries to bring measures of inflation closer to such an ideal. Thus, a technical problem with the original concept of indexed bonds was solved through many years of research in economic theory, and no longer stands as a serious obstacle to their implementation.

Another reason that the indexed bonds then may have been the difficulties that a less educated population would have with index number calculations. Not only are people troubled by "math anxiety" when doing index calculations, but also people have a difficulty with intuitive understanding of the indexation concept. If this is true today, then it is all the more likely to have been true in colonial America.

In 1997, I did a survey study of randomly selected people in the United States and Turkey to try to find what is the reason for their relative lack of interest in indexed bonds. Turkey was included for comparison, since Turkey was a high very high inflation country then. I first tried to find out whether the general public could understand the concept of indexation, even testing them with a 
simple arithmetic problem that related to the basic issues of indexation. More or less, people who agreed to answer the questionnaires in both countries seemed to be able to deal with the concept of indexation if challenged to do so.

Thus, there are certainly plenty of people around who are confident of their understanding of indexation. And yet, some of these same people who rose to the challenge would also say that they did not want the indexation. There appeared to be no logical explanation for this resistance. One of the respondents explained that "I want to know how much money I will be getting." Perhaps that statement just captures the basic feeling as well as any short statement could. There seems to be a habit of wanting money for its own sake, and of mistrusting mathematical formulas.

Perhaps this resistance to indexation is another reason that the 1780 indexation scheme did not catch on. The only example we have of private indexation inspired by the public indexation scheme implicit in the depreciation notes is the example of President Langdon of Harvard. Then as now, only the intellectuals and academics, apparently, enthusiastically embraced indexation.

The example of Harvard President Langdon calls to mind an experience of mine of a few years ago. When I talked to a treasury official in 1996 about possible plans for the issuance of U.S. indexed bonds, I was told that there was a joke at the U.S. Treasury Department then that if and when the indexed bonds are one day issued, Treasury should send the prospectus to the membership roster of the American Economics Association. These are the only people likely to be really interested, so the joke went. Of course, the indexed bonds issued in the United States did get off to a slow start, but now comprise approximately $2 \%$ of the national debt. So, the demand for indexation has moved considerably beyond the economists, and the demand might well have extended far beyond President Langdon in the $18^{\text {th }}$ century, if other conditions had been right. 
In the $18^{\text {th }}$ century, as now, the concept of indexation must have been a difficult one, and the underlying economic theory beyond the intuitive ken of most people then. Economists and financial theorists can understand the concept. But if indexation is to succeed, also a public effort must be undertaken to teach its value to ordinary citizens. The world was apparently not ready for an extensive use of indexed bonds in the $18^{\text {th }}$ century. 
References

Bailey, Martin J., Muth, Richard F., and Nourse, Hugh O., "Regression Method for Real Estate Price Index Construction,” Journal of the American Statistical Association, 58, 933-42, 1963.

Campbell, John Y., and Robert J. Shiller, “A Scorecard for Indexed Government Debt,” NBER Macroeconomics Annual, Ben Bernanke and Julio Rotemberg, editors, pp. 155-97, MIT Press, Cambridge, MA 1996.

Fisher, Willard C., "The Tabular Standard in Massachusetts History," The Quarterly Journal of Economics, 27(3):417-54, May 1913.

Felt, Joseph B., An Historical Account of Massachusetts Currency, Boston: Perkins \& Marvin, 1839.

Gouge, William M., A Short History of Paper Money and Banking in the United States, New York: The Evening Post, 1840.

Jevons, William Stanley, Money and the Mechanism of Exchange, New York: D. Appleton and Co., 1875.

Lowe, Joseph, The Present State of England in Regard to Agriculture, Trade and Finance, 1822.

Palfrey, John Gorham, History of New England, Boston: Little Brown, 1890.

Shiller, Robert J., "Public Resistance to Indexation: A Puzzle," Brookings Papers on Economic Activity, 1997-I.

, “Arithmetic Repeat Sales Price Estimators," Journal of Housing Economics, 1:110-26, March 1991.

Sumner, William Graham, History of American Currency, New York: Henry Holt, 1884. 
Webster, Peletiah, Political Essays on the Nature and Operation of Money, Public Finances and Other Subjects, Pub. During the American War, and Continued up to the Present Year, 1791, Philadelphia: Joseph Crukshank, 1791. 


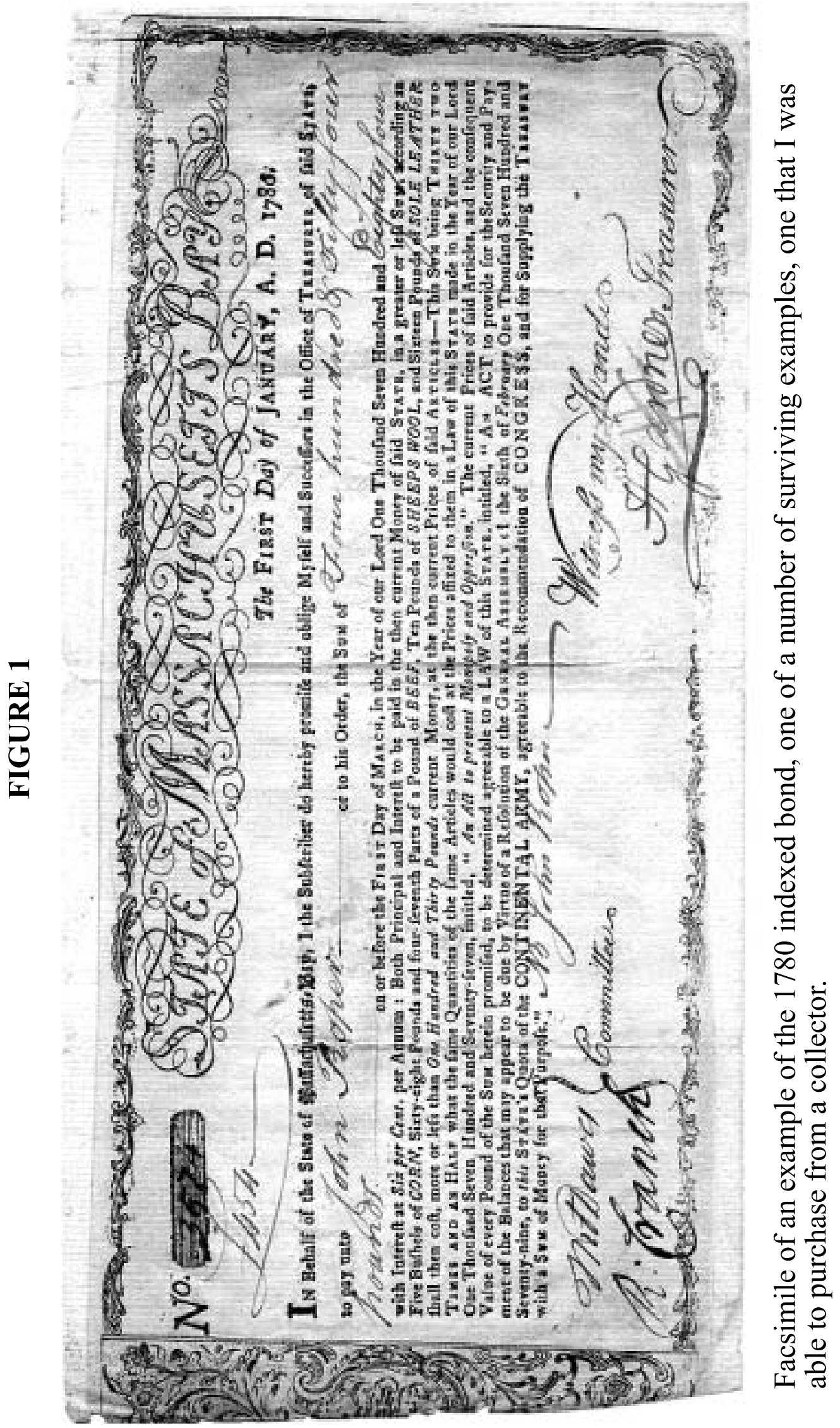




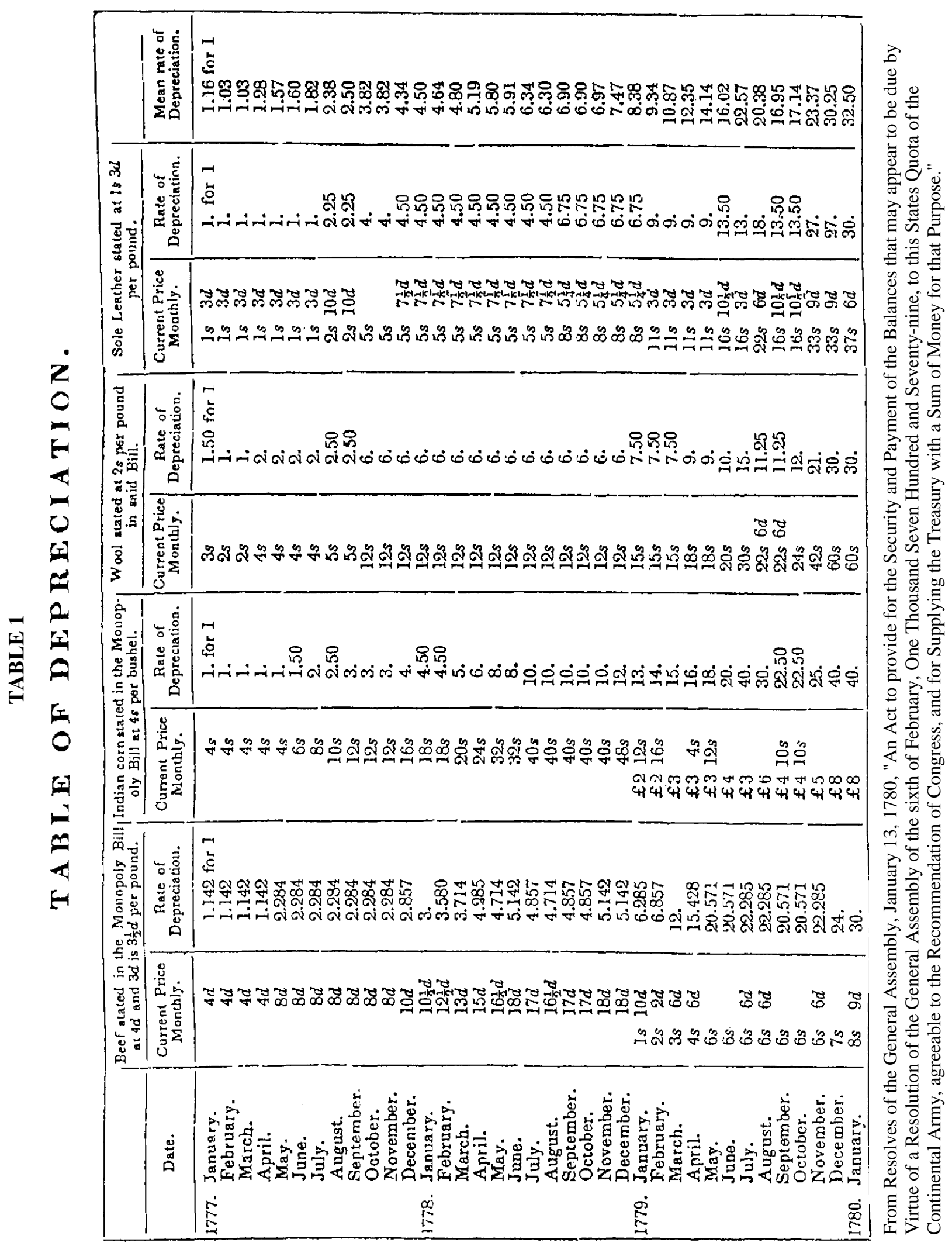




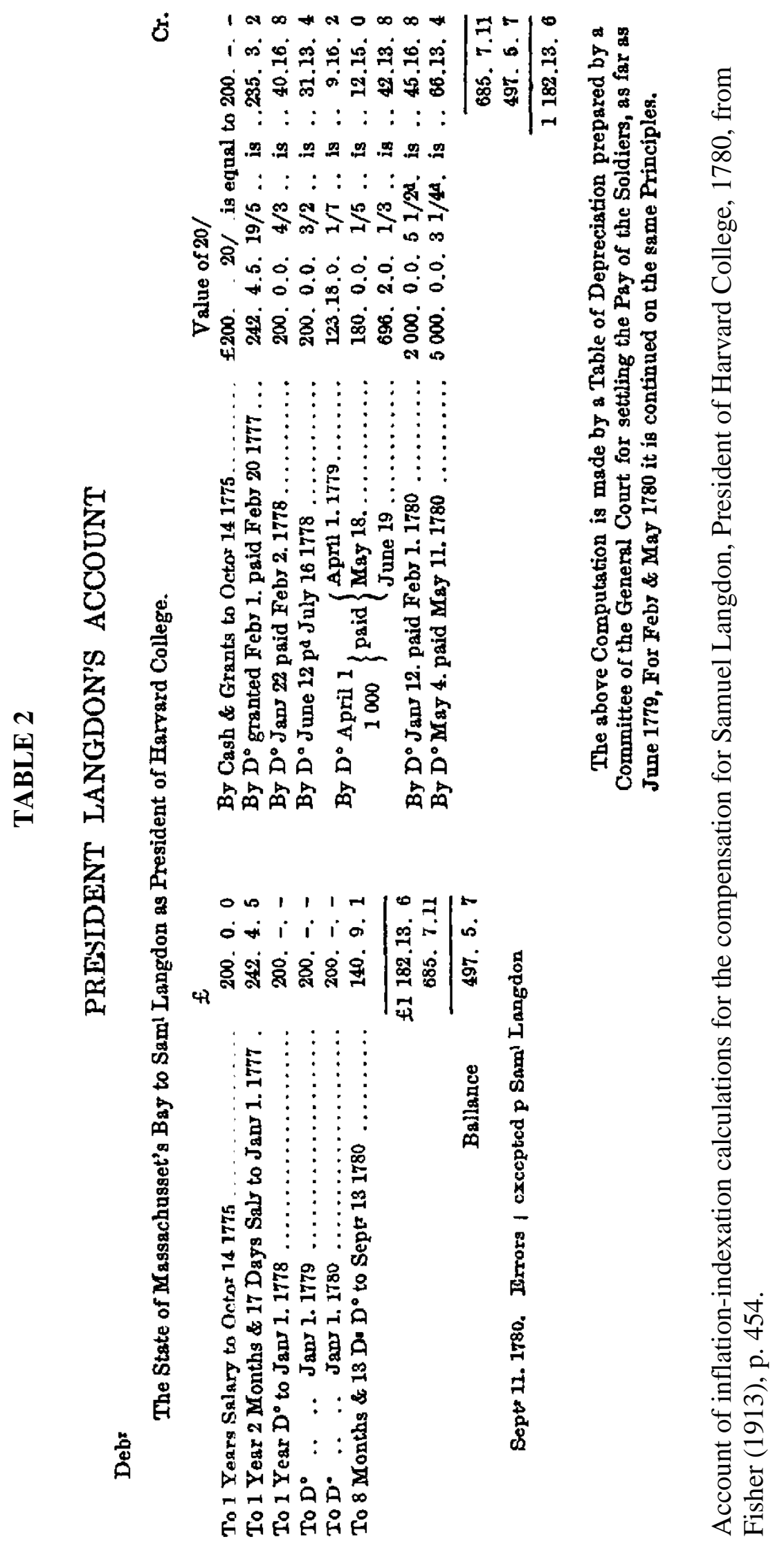

